\title{
Paget Disease of the Breast
}

National Cancer Institute

\section{Source}

National Cancer Institute. Paget Disease of the Breast. NCI Thesaurus. Code C47857.

A malignant neoplasm in which there is infiltration of the skin overlying the breast by neoplastic large cells with abundant pale cytoplasm and large nuclei with prominent nucleoli (Paget cells). It is almost always associated with an intraductal or invasive ductal carcinoma of the breast. The clinical features include focal skin reddening, and eczema. Retraction of the nipple may sometimes occur. 